\title{
T lymphocytes and macrophages in the intestinal tissues of dogs infected with Leishmania infantum
}

\author{
Linfócitos T e macrófagos nos tecidos intestinais de cães infectados com Leishmania infantum
}

Diogo Tiago da Silva ${ }^{1,2}$; Maria Luana Alves ${ }^{1}$; Júlio Cesar Pereira Spada ${ }^{1,2}$; Aline Cristine da Silva ${ }^{1}$; Rita de Cássia Viveiros da Silveira ${ }^{3}$; Trícia Maria Ferreira de Sousa Oliveira ${ }^{4}$; Wilma Aparecida Starke-Buzetti ${ }^{1 *}$

${ }^{1}$ Departamento de Biologia e Zootecnia, Faculdade de Engenharia de Ilha Solteira - FEIS, Universidade Estadual Paulista - UNESP, Ilha Solteira, SP, Brasil

${ }^{2}$ Programa de Pós-graduaçâo em Epidemiologia Experimental Aplicada às Zoonoses, Faculdade de Medicina Veterinária e Zootecnia FMVZ, Universidade de São Paulo - USP, São Paulo, SP, Brasil

${ }^{3}$ Instituto de Biotecnologia, Universidade Estadual Paulista - UNESP, Botucatu, SP, Brasil

${ }^{4}$ Departamento de Medicina Veterinária, Faculdade de Engenharia de Alimentos e Zootecnia - FZEA, Universidade de São Paulo USP, Pirassununga, SP, Brasil

Received January 18, 2017

Accepted May 16, 2017

\begin{abstract}
This study was about a semi-quantitative analysis of $\mathrm{T}$ lymphocytes (CD4 ${ }^{+}$and $\mathrm{CD} 8^{+}$, FoxP3 $3^{+}$regulatory $\mathrm{T}$ cells), and macrophages in the gut wall of dogs naturally infected with Leishmania infantum. Thirteen dogs were divided into three groups: group $1(\mathrm{G} 1, \mathrm{n}=5)$, dogs with canine visceral leishmaniasis (CVL) and infected with $L$. infantum amastigotes in the intestine; group $2(\mathrm{G} 2, \mathrm{n}=5)$, dogs with CVL but without intestinal amastigotes; and group $3(\mathrm{G} 3, \mathrm{n}=3)$, uninfected $\operatorname{dogs}$ (control group). There was no significant difference $(\mathrm{p} \geq 0.05)$ on $\mathrm{CD}^{+}$and Treg cell numbers among the groups, whereas the levels of $\mathrm{CD}^{+} \mathrm{T}$ cells and macrophages were significantly higher in dogs from G1 group than in G2 and G3 ( $\mathrm{p} \leq 0.05)$, especially in intestinal segments with high parasite burden. Parasite burden correlated positively with levels of CD8 ${ }^{+} \mathrm{T}$ cells and macrophages $(\mathrm{p} \leq 0.05)$, but was inversely correlated to levels of CD4 ${ }^{+} \mathrm{T}$ lymphocytes and FoxP3 $3^{+}$Treg cells. In conclusion, in the intestine of dogs with CVL, the increase of $\mathrm{CD}^{+} \mathrm{T}$ cells and macrophages population associated with high parasite burdens, but no changes of $\mathrm{CD}^{+}{ }^{+} \mathrm{T}$ cells and FoxP3 ${ }^{+}$Treg cells suggest a possible immunoregulation by the parasite not dependent on Treg cells.
\end{abstract}

Keywords: $T$ lymphocytes, macrophages, canine visceral leishmaniasis, intestinal tract.

\section{Resumo}

Este estudo foi uma análise semi-quantitativa de linfócitos $\mathrm{T}\left(\mathrm{CD}^{+}, \mathrm{CD}^{+}\right.$e regulatórios - Treg FoxP3 $\left.3^{+}\right)$e macrófagos na parede intestinal de cães naturalmente infectados com Leishmania infantum. Treze cães foram divididos em três grupos: grupo 1 ( $\mathrm{G} 1, \mathrm{n}=5)$ continha cáes com leishmaniose visceral canina (LVC) e com amastigotas intestinais; grupo 2 $(\mathrm{G} 2, \mathrm{n}=5)$ continha cães com LVC, mas sem amastigotas intestinais e o grupo $3(\mathrm{G} 3, \mathrm{n}=3)$ continha cães não infectados (grupo controle). Verificou-se que náo houve diferença significativa $(\mathrm{p} \leq 0.05)$ no número de células $\mathrm{CD}^{+}{ }^{+}$e de Treg entre os grupos, mas o número de células T CD8 ${ }^{+}$e macrófagos foi significativamente superior nos cáes do grupo G1 em relação ao G2 e ao G3 ( $\mathrm{p} \leq 0,05)$, especialmente nos segmentos intestinais com altas cargas parasitárias. As altas cargas parasitarias correlacionaram positivamente com os números de $\mathrm{CD}^{+}$e macrófagos $(\mathrm{p} \leq 0,05)$, mas negativamente com as células $\mathrm{CD}^{+} \mathrm{e}$ Treg. Em conclusão, no intestino dos cáes com LVC, o aumento das populaçôes de células T CD8 ${ }^{+}$e de macrófagos associado a altas cargas parasitárias, mas nenhuma alteração de células T CD4 $4^{+}$e células Treg FoxP3 ${ }^{+}$sugerem uma possível imunorregulação pelo parasita não dependente de células Treg.

Palavras-chave: Linfócito T, macrófagos, leishmaniose visceral canina, trato intestinal.

*Corresponding author: Wilma Aparecida Starke-Buzetti. Departamento de Biologia e Zootecnia, Faculdade de Engenharia de Ilha Solteira - FEIS, Universidade Estadual Paulista - UNESP, Av. Brasil, 56, CEP 15385-000, Ilha 


\section{Introduction}

Visceral leishmaniasis (VL) is a chronic parasitic disease caused by the protozoa Leishmania infantum (Kinetoplastida: Trypanosomatidae), which infects macrophages in a wide variety of mammals, including humans and dogs (LUCA et al., 1999; NIETO et al., 1999).

VL is transmitted to vertebrates by the bite of infected female phlebotomine sandflies, of which Lutzomyia longipalpis (Diptera: Psychodidae) is the main vector of the parasite in the Americas (GALATI et al., 1997; WHO, 2010; WHEELER et al., 2011).

The infection affects the liver, spleen, lymph nodes, and bone marrow and also other organs in the gastrointestinal, central nervous, genital, and urinary systems (BLAVIER et al., 2001). An inflammatory reaction in the gastrointestinal (GI) tract associated with the presence of intramacrophagic Leishmania amastigotes has been reported in experimentally infected dogs (KEENAN et al., 1984) and in naturally infected dogs (FERRER et al., 1991; PINTO et al., 2011; TOPLU \& AYDOGAN, 2011; SILVA et al., 2016). Although uncommon, occurrences of erosive and ulcerative colitis and hemorrhagic diarrhea have been described in dogs in association with severe clinical signs of disease (GONZÁLEZ et al., 1990; FERRER et al., 1991). However, the prevalence of Leishmania parasitism detected in the colonic mucosa through colonoscopy, but without colitis, was surprisingly high in dogs with symptomatic leishmaniasis (ADAMAMA-MORAITOU et al., 2007).

Leishmania has a strong tropism for macrophages, but they can also infect dendrict cells and other non-phagocytic mammalian cells (NADERER \& MCCONVILLE, 2008). It is well established that phagocytic cells can participate in parasite control via processes that depend on free radicals secreted during the respiratory burst pathway activation in neutrophils and macrophages (RODRIGUES et al., 2007).

Macrophages are basically classified as M1 or M2 macrophages and their heterogeneity derives from the distinct effects of cytokines expressed by Th1 (T helper 1 ) or Th2 (T helper 2) cells during their differentiation. M1 macrophages after stimulation with LPS (lipopolysaccharide) are activated to produce NO (nitric oxide) from arginine, which controls the proliferation of intracellular parasites. M2 macrophages after the same stimulus increase the metabolism of arginine to ornithine, producing polyamines and promote the proliferation of parasites (MILLS et al., 2000).

Leishmania spp. have high genetic variability and the induction of susceptibility or resistance are necessarily different among these species (PASSERO et al., 2010). Even though a protective role for $\mathrm{T}$ lymphocytes against infection by Leishmania has demonstrated in animal models, Bourdoiseau et al. (1997) suggested the absence of an effective immune response of $\mathrm{CD} 4^{+}$ $T$ cells to eliminate $L$. infantum in infected dogs, which would be caused by a reduction of these cells associated with increased parasite loads in macrophages.

However, it has been shown that depletion of $\mathrm{CD}^{+} \mathrm{T}$ cells in Leishmania major-infected $\mathrm{BALB} / \mathrm{c}$ mice allows the development of effector functions and activation of $\mathrm{CD} 8^{+} \mathrm{T}$ cells. This suggests that the cross-talk between $\mathrm{CD}^{+}$and $\mathrm{CD} 8^{+} \mathrm{T}$ cells is crucial for efficient host defense, because in the absence of $\mathrm{CD} 8^{+} \mathrm{T}$ cells,
$\mathrm{CD}^{+} \mathrm{T}$ cells alone were unable to induce cure in $\mathrm{BALB} / \mathrm{c}$ mice. The effector function of $\mathrm{CD} 8^{+} \mathrm{T}$ cells probably depends on IFN- $\gamma$ production (MÜLLER et al., 1991; HERATH et al., 2003).

CD8 T cells, similar to CD4 T cells, are classified into two subsets of cytolytic effector cells with distinct cytokine patterns, termed cytotoxic T lymphocytes 1 (Tc1) and cytotoxic T 2 (Tc2). Tc1 cells secrete a Th1-type cytokine pattern, including IL-2 and IFN- $\gamma$, whereas Tc2 cells produce Th2-like cytokines, including IL-4, IL-5 and IL-10, (DELFS et al., 2001; OHTA et al., 2004). In rats infected with $L$. infantum, CD8+ T cells isolated expressed IFN- $\gamma$ and TNF, improving the cellular cytotoxic activity against Leishmania spp., suggesting that CD8+ T-cells displayed a Tc1 pattern of differentiation, which was important for the control of the parasite (TSAGOZIS et al., 2003). For Ohta et al. (2004) there is increasing evidence that $T h 1 / T h 2$ and $T c 1 / T c 2$ mediated cytokine imbalance has been of pathogenetic importance in various diseases, such as allergic and autoimmune diseases.

The FoxP3 (Forkhead FoxP3 ${ }^{+}$) protein is a key component in regulating the development and function of regulatory $\mathrm{T}$ (Treg) cells (BOER et al., 2007) and an excellent marker of these cells (FONTENOT et al., 2003). In Leishmania-susceptible mice, Treg cells promote the suppression of excessive immune responses mediated by Th2 cells. In resistant animals, however, Treg cells control Th1 response, resulting in the persistence of a small number of parasites and in the establishment of immunity against reinfection (MENDEZ et al., 2004).

Figueiredo et al. (2014) found no correlation between the clinical signs of canine visceral leishmaniasis (CVL) and pathological, immunological, and parasitological findings in dogs with $L$. infantum amastigotes in GI tissues. However, different segments of the GI tract of infected dogs showed different immunological and parasitological responses. Specifically, increased expression of CD4, FoxP3, IL-10, TGF- $\beta$, IFN- $\gamma$, and TNF- $\alpha$ and reduced CD8 and IL- 4 expression were observed in canine GI tracts positive for $L$. infantum amastigotes both in the jejunum and colon (FIGUEIREDO et al., 2014).

Even though the presence of Leishmania amastigotes in the GI tract is well established, few studies have investigated the role of immune effector cells such as $\mathrm{CD} 4^{+}$and $\mathrm{CD} 8^{+} \mathrm{T}$ lymphocytes, Treg cells, or macrophages in the immunology of this organ in L. infantum-infected dogs. Thus, this study was about a semi-quantitative analysis of $\mathrm{T}$ lymphocytes $\left(\mathrm{CD}^{+}, \mathrm{CD} 8^{+}\right.$, Treg FoxP $3^{+}$) and macrophages in the gut wall of dogs naturally infected with $L$. infantum.

\section{Materials and Methods}

\section{Animals and study location}

For this study, 13 dogs were selected from both Ilha Solteira

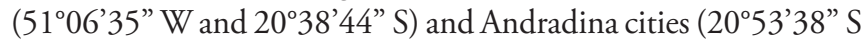
and $\left.51^{\circ} 23^{\prime} 1^{\prime \prime} \mathrm{W}\right)$, which are endemic areas for CVL located in the northwestern region of the state of Sáo Paulo (SP), Brazil. Ten dogs were naturally infected with $L$. infantum and three uninfected dogs were selected as controls. 
The dogs were divided into three groups: group $1(\mathrm{G} 1, \mathrm{n}=5)$, dogs naturally infected with $L$. infantum detected by indirect enzyme immunoassay (ELISA), indirect immunofluorescence (IFAT), and polymerase chain reaction (PCR) from blood, and with intestinal amastigotes detected by immunohistochemistry and PCR of intestinal tissues; group $2(\mathrm{G} 2, \mathrm{n}=5)$, dogs naturally infected with L. infantum detected by ELISA, IFAT, and PCR from blood, but without intestinal amastigotes on immunohistochemistry and PCR of intestinal tissues; and group $3(\mathrm{G} 3, \mathrm{n}=3)$, L. infantum-uninfected dogs (control group) on serological, parasitological, and molecular exams.

The study was approved by the Ethics Committee for Animal Use (CEUA) of São Paulo State University, Ilha Solteira Campus (FEIS-UNESP), Department of Biology and Animal Science, under protocol no. 06/2014-CEUA.

\section{CVL diagnosis}

\section{CVL-positive dogs (G1 and G2 groups)}

During an epidemiological survey, the dogs were diagnosed with CVL by the Zoonosis Control Center (ZCC) of Ilha Solteira using the following methods: (a) direct parasitological examinations of popliteal or pre-scapular lymph node aspirate stained with Panoptic staining kit (Laborclin ${ }^{\circledR}$, Pinhais, PR, Brazil) and (b) Dual Path Platform (DPP ${ }^{\circledR}$ ) immunochromatographic test (Chembio Diagnostic Systems Inc., Medford, NY, USA) as a screening test and an indirect ELISA test (Biomanguinhos kit; Fiocruz, Rio de Janeiro, RJ, Brazil) for confirmation. Following confirmation, 10 symptomatic infected dogs were spontaneously delivered at ZCC by their guardians to be euthanized and were kindly donated by the ZCC for this study.

The serological tests of these animals were repeated in our laboratory using an indirect ELISA test and IFAT according to Oliveira et al. (2008). The optical density cut-off for ELISA and antibody titration factor for IFAT were 0.3802 and 1:40, respectively. The titer of anti-Leishmania antibodies in IFAT ranged from 1:640 to 1:2560. The cut-off point of the ELISA test was determined multiplying the mean of the negative reference sera in absorbance values by the coefficient 2.5 . The negative reference sera were from uninfected dogs from non-endemic areas for canine leishmaniasis.

For DNA extraction from blood and tissue samples of the intestine, we used the QIAamp Blood and Tissue kit (Qiagen, Santa Clarita, CA, USA). The amplification of the 447-base pair (bp) DNA fragments from the promastigote kinetoplast mini circle was performed by PCR using the pair of oligonucleotide primers to $L$. infantum MC1 (5'-GTT CGA TTT TTT TCT AGC TG-3') and MC2 (5'-CCC CCA TTT TTC CGA TTT TG-3') as described by Cortes et al. (2004).

The positive control for the reactions was a DNA sample from L. infantum (syn. Leishmania chagasi, MCAN/BR/1984/ CCC-17.481) provided by the Laboratory of Leishmaniasis of the Leishmanioses Research Center at Fiocruz, Rio de Janeiro, Brazil and the negative control was sterile deionized water. The PCR products were visualized under ultraviolet light (UV) after 1.5\% agarose gel electrophoresis containing the SYBR ${ }^{\circledR}$ safe dye (Invitrogen ${ }^{\circledR}$, Carlsbad, CA, USA) in Tris-borate buffer (pH 8.0). The 100-bp ladder K180 DNA Molecular Weight Marker (Amresco ${ }^{\circledR}$, Solon, $\mathrm{OH}, \mathrm{USA}$ ) was used to estimate the size of the amplicon.

\section{Control group - CVL-uninfected dogs (G3)}

The CVL-uninfected dogs (G3) were euthanized after injuries suffered by traffic accidents. Before death, the animals were attended at a veterinary clinic where feces, urine, lymph node, bone marrow, and blood samples were collected for clinical, parasitological, biochemical, serological, and molecular exams. The results of all exams were negative and the dogs had no any clinical signs of leishmaniasis. After euthanasia, samples of intestinal tissues were collected.

The hepatic and renal function of control dogs (G3) was assessed through measurements of alanine aminotransferase (ALT2S kit, ref 04657373), aspartate aminotransferase (ASTL kit, ref 04657543), urea (UREAL kit, ref 04657616), and creatinine (CREJ2 kit, ref 05401755) using the Cobas c111 analyzer (Roche Diagnostics International Ltd, Rotkreuz, Switzerland). The results were compared with reference values for healthy dogs and control dogs had normal enzyme levels.

\section{Euthanasia and necropsy procedures for tissue sample collection}

Infected dogs were euthanized and necropsied at the ZCC of Ilha Solteira, SP. Euthanasia was performed following the procedure no. 1000/2012 from the Brazilian Federal Council of Veterinary Medicine (CFMV) and in accordance with Decree no. 51,838 of Brazilian Federal law published on March 14, 1963, which recommends that dogs infected with Leishmania be euthanized. Briefly, the animals received Diazepam $(1 \mathrm{mg} / \mathrm{Kg})$ as a preanesthetic drug (MPA) and then sodium thiopental (Thiopentax ${ }^{\circledR}$, SP, Brazil, $30 \mathrm{mg} / \mathrm{Kg}$ ) anesthesia. After the anesthesia it was intravenously administered a potassium chloride solution (10\%) for animal death.

Following euthanasia, the abdominal cavities of dogs were opened for examination and organs and tissues were removed. First, the small intestine (duodenum, jejunum and ileum) was separated from the large intestine (ascending colon) and 0.5 - to $1 \mathrm{~cm}$ long fragments were collected, washed with phosphate buffered saline (PBS 0.01 M, pH=7.4), and fixed in 10\% buffered formalin in $0.01 \mathrm{M} \mathrm{PBS}$ for $24 \mathrm{~h}$ for histopathological and immunohistochemical procedures.

The necropsy and tissue collection of control dogs followed the same procedures as described above.

Feces samples and intestinal contents of the small and large intestines were collected after death, identified, packed in ice, and sent to the laboratory for parasitological analysis. The results showed that the dogs did not have any gastrointestinal parasites, with the exception of $L$. infantum amastigotes in the intestinal tissues of dogs from the G1 group. 


\section{Histological procedures}

The intestinal tissue samples collected from G1, G2, and G3 dogs were fixed in $10 \%$ formalin in $0.01 \mathrm{M}$ PBS for histochemistry and immunohistochemistry.

Histochemistry: The intestinal tissues were fixed, embedded in paraffin, cut in 5- $\mu \mathrm{m}$ thick sections and stained with hematoxylin and eosin (HE) for histological examination. Histochemically stained macrophages were identified in tissues from infected and uninfected dogs. Three sections of each intestinal tissue were evaluated under a light microscope at 40x and/or 100x magnification.

Immunohistochemistry: Intestinal tissue samples were previously hydrated in successive passages in xylene and ethanol. Initially, the endogenous peroxidase enzyme was blocked using 3\% hydrogen peroxide solution $\left(\mathrm{H}_{2} \mathrm{O}_{2}\right)$ diluted in $0.01 \mathrm{M} \mathrm{PBS}(\mathrm{pH}=7.4)$ and non-specific secondary antibody reactions were inhibited using the normal serum of the animal of which the secondary antibody was made (goat serum) in 1:50 dilution. Samples were incubated with the primary antibody in a humid chamber at $4{ }^{\circ} \mathrm{C}$ overnight. After three rinses with PBS, samples were then incubated with the secondary antibody for $1 \mathrm{~h}$ at room temperature, and after successive rinses, an avidin-biotin peroxidase complex (Vectastain ABC Kit; Vector Laboratories Inc., Burlingame, CA, USA) was applied for immune reaction. After appropriated rinses with PBS, 50 to $100 \mu$ lof freshly prepared solution of horseradish peroxidase substrate $\left(V_{E C T O R}{ }^{\circledR}\right.$ NovaRED $^{\mathrm{TM}}$; Vector Laboratories Inc., SK-4800) was placed on each tissue section and left for $5 \mathrm{~min}$. After rinsing in distilled water, tissues were counterstained with Mayer hematoxylin, dehydrated, and the slides were mounted and coversliped using Canada balsam.

As reaction control, one slide of each tissue was not incubated with the primary antibody. In addition, tissues from dogs in the control group (CVL-uninfected dogs) were used as negative control and tissues from CVL-infected dogs were used as the positive control of the reaction. Two slides of each tissue from groups G1, G2, and G3 were analyzed.

Leishmania infantum amastigote immunostaining was performed according to the procedures described by Tafuri et al. (2004). The primary antibody used was the immune serum of L. infantum-naturally infected dogs (diagnosed by ELISA and RIFI; titer=1: 2560) and the secondary antibody was the biotinylated rabbit anti-IgG antibody produced in goat (immune reaction crossed with dogs; in 1: 500 dilution).

Tissue antigen retrieval using TRIS $(\mathrm{pH}=7.6)+$ trypsin (1:250) was performed for immunostaining of $\mathrm{CD}^{+}$and $\mathrm{CD} 8^{+}$ lymphocytes for $30 \mathrm{~min}$. The primary antibodies used were antidog monoclonal antibodies produced in rat anti-CD4 (AbD serotec-MCA1038GA, Bio-Rad Laboratories, Hercules, CA, USA) and anti-CD8 T cells (AbD serotec-MCA1039GA, Bio-Rad Laboratories). Next, we added the biotinylated anti-rat secondary antibody produced in goat (AbD Serotec-STAR131B, Bio-Rad Laboratories) diluted 1:200, which reacted specifically with the respective primary antibodies.

Fluorescence immunolabeling: Treg cells were detected using anti-mouse/rat FoxP3 antibody conjugated with a fluorescein molecule (eFluor ${ }^{\circledR}$ 570; eBioscience, San Diego, CA, USA), which also detects dog FoxP3. The tissue was prepared according to standard techniques for histology and for antigen retrieval using TRIS buffer ( $\mathrm{pH}=7.6)+\operatorname{trypsin}(1: 250)$. Next, $5 \mu \mathrm{l}$ of undiluted primary antibody was added to each tissue section and after $30 \mathrm{~min}$ the material was washed with PBS $(\mathrm{pH}=7.4$, $0.01 \mathrm{M}$ ) and the slides were covered with a cover slip in glycerin. The material was observed under a fluorescence microscope (Olympus, BX-FLA).

\section{Semi-quantitative analysis}

Leishmania infantum amastigotes: The semi-quantitative analysis was performed only in intestinal tissues with L. infantum amastigotes. For this analysis, 100 positive visual microscopic fields of the intestinal tissues were analyzed at 40x magnification and the positive cells containing the parasites were counted. The tissues were scored according to parasite burden (+ to ++++$)$ and positive cell scores (1 to 4 ), as follows: no positive cells (without amastigotes) or negative tissues; $1-50$ positive cells (score $1 ;+$ ) or low parasite burden; 51-100 positive cells (score $2 ;++$ ), or moderate parasite burden; 101-200 positive cells (score 3; +++ ), or intense parasite burden; > 201 positive cells (score $4 ;++++$ ), or very intense parasite burden.

$\mathrm{CD}^{+}, \mathrm{CD8}^{+}$, and FoxP3 ${ }^{+} \mathrm{T}$ lymphocytes and macrophages: For a semi-quantitative analysis of T lymphocytes $\left(\mathrm{CD}^{+}, \mathrm{CD}^{+}\right.$, and Treg) and macrophages, approximately 100 visual microscopic fields were visualized under a microscope at 100x magnification. The cellular score was determined by the number of positive microscopic fields where at least one cell from each cell type was detected, as follows: $\leq 25$ positive microscopic fields were classified as having low cellular levels (+) and score 1; 26-50 positive fields, moderate cellular levels (++, score 2$)$; $51-75$ positive fields, high cellular levels (+++, score 3$)$; and $>76$ positive fields were classified as having very high cellular levels $(++++$, score 4$)$.

All cells evaluated were from the intestinal mucosa, represented by crypt-villus units (CVU) in three segments of the small intestine and one of the large intestine.

\section{Statistical analysis}

The residues were submitted to the Shapiro-Wilks normality and outliers test, the homogeneity of the variances was evaluated by the Levene test. The mean scores for the semi-quantitative $\mathrm{T}$ lymphocytes $\left(\mathrm{CD}^{+}, \mathrm{CD}^{+}\right.$and Treg FoxP3 $\left.{ }^{+}\right)$and macrophages from the experimental groups of dogs (G1, G2 and G3) were analyzed by ANOVA using the F test, and the comparison mean of the groups was performed according to the Duncan's test, using the "agricolae" data package.

The correlation between cellular scores and parasite burden was determined using the Spearman correlation test. For both tests, 95\% confidence intervals were calculated and $\mathrm{p}$ values $\leq 0.05$ were considered significant. All analyses were performed using $\mathrm{R}$ statistical software version 3.1.1 (R CORE TEAM, 2017). 


\section{Results}

According to the histological analysis, dogs from the G1 group had L. infantum amastigotes in at least one intestinal segment (duodenum, jejunum, ileum, or ascending colon). Two dogs in the $\mathrm{G} 1$ group showed a parasite burden ranging from high (score $3 ;+++)$ to very high (score $4 ;++++$ ) in all intestinal segments (Table 1, Figure 1A). In addition, the colon was the intestinal segment with the highest parasite burden and also the one more frequently infected; however, there was no significant difference in parasite burden scores between intestinal segments (Table 1).

Macrophages were distributed in the mucosa (CVU) and submucosa of dogs from the G1, G2, and G3 groups (Figure 1B), but macrophage scores between the G1, G2, and G3 groups in the mucosa were significantly different $(\mathrm{G} 1>\mathrm{G} 2>\mathrm{G} 3, \mathrm{p} \leq 0.05)$ (Table 2). Macrophage scores in G1 dogs ranged from $2(++)$ to $4(++++)$, and the highest score was detected in animals with highest parasite burden (Tables 1 and 2). When each intestinal segment was analyzed, macrophage scores in the duodenum and colon were significantly higher than in the jejunum and ileum in G1 dogs and significantly different from that of G2 and G3 dogs. Most dogs in the G2 group had moderate macrophage scores $(2 /++)$, but their scores were higher than in the G3 group. In addition, macrophage scores of dogs from G1 and G2 groups were significantly different from the control group (G3) only in the duodenum (Table 2).

There was no significant difference in $\mathrm{CD}^{+} \mathrm{T}$ cell levels among all experimental groups $(\mathrm{p} \geq 0.05)$. Similarly, no significant difference was observed among all intestinal segments (Table 3, Figures $2 \mathrm{~A}$ and $\mathrm{C}$ ). in contrast, the semi-quantitative analysis showed that $\mathrm{CD}^{+} \mathrm{T}$ lymphocyte scores were significantly higher in the small and large intestines $(\mathrm{p} \leq 0.05)$ in dogs from G1 and G2 groups in relation to the control dogs (G3) (Table 4, Figures $2 \mathrm{~B}$ and $\mathrm{D})$. In addition, $\mathrm{CD} 8^{+} \mathrm{T}$ lymphocyte scores in the ileum (Peyer's patches, Figure 2B), duodenum and colon of dog's numbers 4 and 5 from G1 group were high in these organs, which also had very high parasite burdens (score $3-4 ;+++,++++$ ) (Tables 1 and 4).

Table 1. Parasite burden scores $(1[+]$ to $4[++++])$ in intestinal (duodenum, jejunum, ileum, and colon) mucosal tissues (crypt-villus unit CVU) from dogs naturally infected with Leishmania infantum. Ilha Solteira, SP, Brazil, 2017.

\begin{tabular}{|c|c|c|c|c|c|}
\hline \multicolumn{6}{|c|}{ Parasite burden scores for Leishmania infantum amastigotes in intestinal mucosal (CVU) tissues } \\
\hline Group & Dog & Duodenum & Jejunum & Ileum & Colon \\
\hline \multirow{5}{*}{ Group 1 (G1) } & 01 & $\mathrm{~N}$ & $\mathrm{~N}$ & $\mathrm{~N}$ & $3(+++)$ \\
\hline & 02 & $2(++)$ & $\mathrm{N}$ & $2(++)$ & $\mathrm{N}$ \\
\hline & 03 & $\mathrm{~N}$ & $\mathrm{~N}$ & $\mathrm{~N}$ & $3(+++)$ \\
\hline & 04 & $4(++++)$ & $3(+++)$ & $4(++++)$ & $3(+++)$ \\
\hline & 05 & $3(+++)$ & $2(++)$ & $3(+++)$ & $4(++++)$ \\
\hline Average (scores) & & 1.8 & 1.0 & 1.8 & 2.6 \\
\hline
\end{tabular}

Note: $\mathrm{N}$ = negative. According to the F-test, there is no significant difference to the level of 5\% probability (p $\leq 0.05$ ). R version 3.1.1 (R CORE TEAM, 2017).
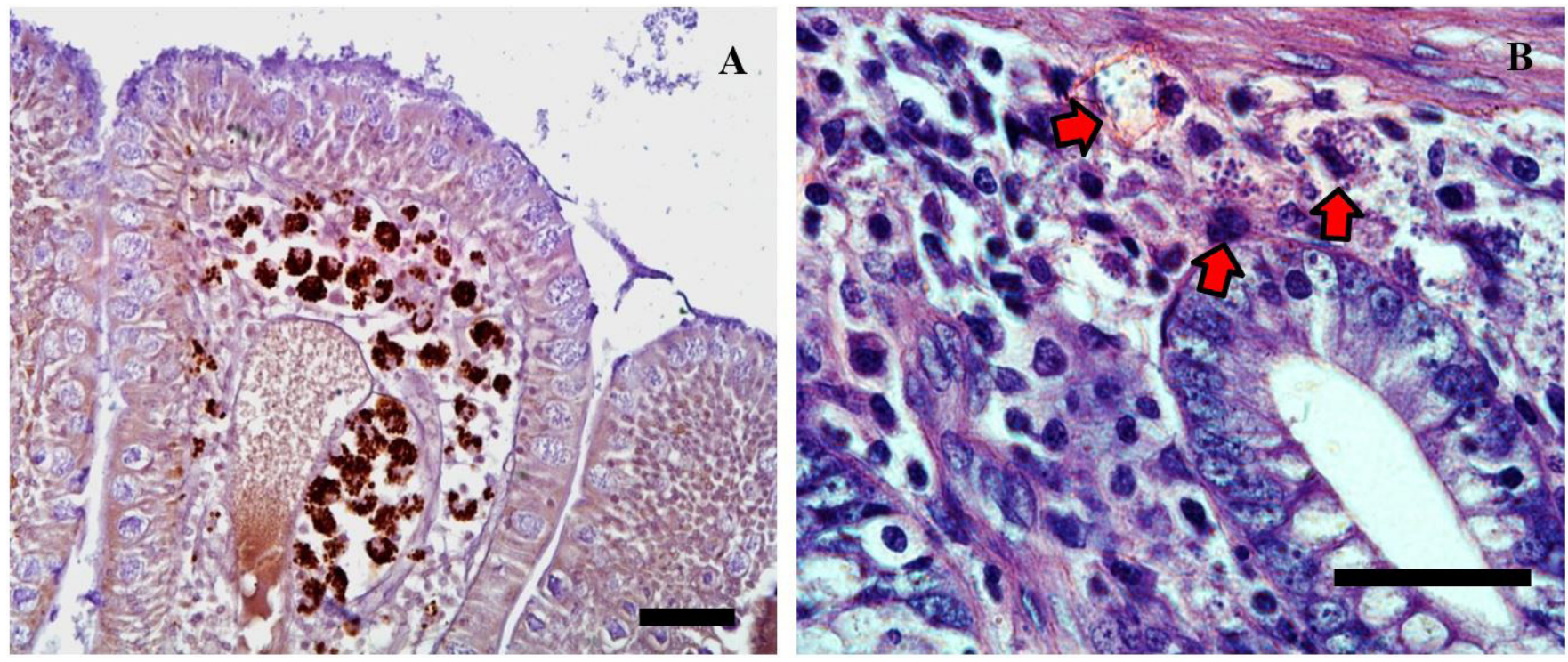

Figure 1. Histological sections of the intestine of dogs with CVL. (A) (ileum) Numerous macrophages with amastigotes of Leishmania infantum aggregated in the lamina propria at the tips of villi (magnification: 40x, staining: immunohistochemistry); (B) (colon) Basal crypt and submucosa. Red arrows = hypertrophic macrophages with amastigote (magnification: 100x, staining: H\&E). Bars $=50 \mu \mathrm{m}$. Ilha Solteira, SP, Brazil, 2017. 
Table 2. Semi-quantitative analysis of macrophages in intestinal (duodenum, jejunum, ileum, and colon) mucosal tissues (crypt-villus unit CVU) from dogs naturally infected with Leishmania infantum and uninfected dogs. Scores range from 1 to 4. Ilha Solteira, SP, Brazil, 2017.

\begin{tabular}{|c|c|c|c|c|c|}
\hline \multicolumn{6}{|c|}{ Average scores for macrophages by intestinal segment } \\
\hline Group & Dogs & Duodenum & Jejunum & Ileum & Colon \\
\hline G1 & $\mathrm{N}=5$ & $3.2^{\mathrm{aA}}$ & $2.6^{\mathrm{aB}}$ & $3.0^{\mathrm{aB}}$ & $3.8^{\mathrm{aA}}$ \\
\hline G2 & $\mathrm{N}=5$ & $3.0^{\mathrm{bA}}$ & $2.4^{\mathrm{aB}}$ & $2.6^{\mathrm{abAB}}$ & $2.2^{\mathrm{bB}}$ \\
\hline G3 & $\mathrm{N}=3$ & $2.0^{\mathrm{cA}}$ & $2.0^{\mathrm{aA}}$ & $2.0^{\mathrm{bA}}$ & $2.0^{\mathrm{bA}}$ \\
\hline \multicolumn{6}{|c|}{ Average of the intestines } \\
\hline Group & & Sm & & Large intestine & Intestinal tract (all) \\
\hline G1 & & & & $3.8^{\mathrm{aA}}$ & $3.15^{\mathrm{aA}}$ \\
\hline G2 & & & & $2.2^{\mathrm{bB}}$ & $2.55^{\mathrm{bAB}}$ \\
\hline G3 & & & & $2.0^{\mathrm{bA}}$ & $2.0^{\mathrm{cA}}$ \\
\hline
\end{tabular}

Note: Comparison of averages by Duncan's test. Different lowercase letters ( $\mathrm{a}, \mathrm{b}$ and $\mathrm{c}$ ) indicate statistical significance between lines and different capital letters (A, B and C) indicate significance statistical between columns at 5\% of probability ( $\mathrm{p} \leq 0.05)$. Program R version 3.1.1 (R CORE TEAM, 2017).

Table 3. Semi-quantitative analysis of CD4 ${ }^{+} \mathrm{T}$ lymphocytes in intestinal (duodenum, jejunum, ileum, and colon) mucosal tissues (crypt-villus unit - CVU) from dogs naturally infected with Leishmania infantum and uninfected dogs. Scores range from 1 to 4 . Ilha Solteira, SP, Brazil, 2017.

\begin{tabular}{|c|c|c|c|c|c|}
\hline \multicolumn{6}{|c|}{ Average scores for $\mathrm{CD4}^{+} \mathrm{T}$ lymphocytes by intestinal segment } \\
\hline Group & Dogs & Duodenum & Jejunum & Ileum & Colon \\
\hline G1 & $\mathrm{N}=5$ & $1.4^{\mathrm{aA}}$ & $1.2^{\mathrm{aA}}$ & $1.2^{\mathrm{aA}}$ & $1.2^{\mathrm{aA}}$ \\
\hline G2 & $\mathrm{N}=5$ & $1.0^{\mathrm{aA}}$ & $1.4^{\mathrm{aA}}$ & $1.0^{\mathrm{aA}}$ & $1.4^{\mathrm{aA}}$ \\
\hline G3 & $\mathrm{N}=3$ & $1.0^{\mathrm{aA}}$ & $1.0^{\mathrm{aA}}$ & $1.0^{\mathrm{aA}}$ & $1.0^{\mathrm{aA}}$ \\
\hline \multicolumn{6}{|c|}{ Average of the intestines } \\
\hline Group & & & & Large intestine & Intestinal tract (all) \\
\hline G1 & & & & $1.2^{\mathrm{aA}}$ & $1.25^{\mathrm{aA}}$ \\
\hline G2 & & & & $1.4^{\mathrm{aA}}$ & $1.2^{\mathrm{aA}}$ \\
\hline G3 & & & & $1.0^{\mathrm{aA}}$ & $1.0^{\mathrm{aA}}$ \\
\hline
\end{tabular}

Note: According to the F-test, there is no significant difference to the level of $5 \%$ probability ( $\mathrm{p} \leq 0.05)$. For lowercase letters (a, b and c) the comparisons were made in lines and for capital letters (A, B and C) the comparisons were made in columns. R version 3.1.1 (R CORE TEAM, 2017).

The presence of regulatory $\mathrm{T}$ cells $\left(\mathrm{FoxP}^{+}\right)$was low in all intestinal tissues (small or large intestines) of dogs in the G1, G2, and G3 groups and no significant difference was observed in FoxP3 expression among all experimental groups ( $\mathrm{p} \geq 0.05$; Table 5, Figures 2E and F). Few or none FoxP3 ${ }^{+} \mathrm{T}$ cells were observed in control samples (G3). Thus, dogs with intense parasite burden (Table 1) also had low scores for this type of regulatory cell (Table 5).

The cellular scores of $\mathrm{CD}^{+}, \mathrm{CD}^{+}$, Treg $\left(\mathrm{FoxP}^{+}\right)$lymphocytes, and macrophages were compared in pairs and with parasite burden using correlation analysis. Parasite burden and $\mathrm{CD} 4^{+} \mathrm{T}$ lymphocyte scores showed a significant negative correlation ( $\mathrm{p} \leq 0.05)$ : tissues with higher parasite burdens had low $\mathrm{CD}^{+} \mathrm{T}$ cell levels ( $\mathrm{rs}=-0.89$, $\mathrm{p}=0.041$ ). Similarly, $\mathrm{CD}^{+} \mathrm{T}$ cell levels correlated negatively with the levels of $\mathrm{CD}^{+} \mathrm{T}$ cell ( $\mathrm{rs}=-0.89, \mathrm{p}=0.043$ ) and macrophages ( $r s=-0.92, p=0.028)$, in the same intestinal region of dogs from G1 group (Table 6).

In contrast, $\mathrm{CD}^{+} \mathrm{T}$ lymphocyte levels correlated positively with the levels of macrophages in the large intestine of G1 dogs ( $r s=0.97, \mathrm{p}=0.006)$ and in the small intestine of G2 dogs ( $r s=0.89, \mathrm{p}=0.041$; Table 6$)$. The levels of both cell types $\left(\mathrm{CD}^{+}\right.$ and macrophages) also correlated positively with parasite burden in the large intestine ( $r s=0.91, p=0.03$ and $r s=0.88, p=0.046$, respectively) (Table 6). Conversely, no significant correlation was observed between parasite burden and cell levels in the small intestine of $\mathrm{G} 1$ dogs.

There was a negative correlation between FoxP3 ${ }^{+} \mathrm{T}$ cell scores and parasite burden in the small intestine of G1 dogs ( $r s=-0.89$, $\mathrm{p}=0.041$ ), but no significant correlation was observed in the large intestine of animals from the same group (Table 6).

In Figure 3 it is possible to comparatively evaluate the distribution of $\mathrm{T}$ lymphocytes $\left(\mathrm{CD}^{+}, \mathrm{CD}^{+}\right.$, and $\left.\mathrm{FoxP}^{+}\right)$and macrophages along the small and large intestine from the experimental groups (G1, G2, and G3).

\section{Discussion}

Leishmania infantum is an intracellular parasite that multiplies in macrophages residing in several organs and lymphoid tissues, including intestinal tissues of dogs (PINTO et al., 2011, 2013; SILVA et al., 2016), causing clinical and pathological alterations (FEITOSA et al., 2000). Anderson et al. (1980) observed macrophage infected with $L$. infantum in the lamina propria and submucosa of the stomach, duodenum, jejunum, ileum, 

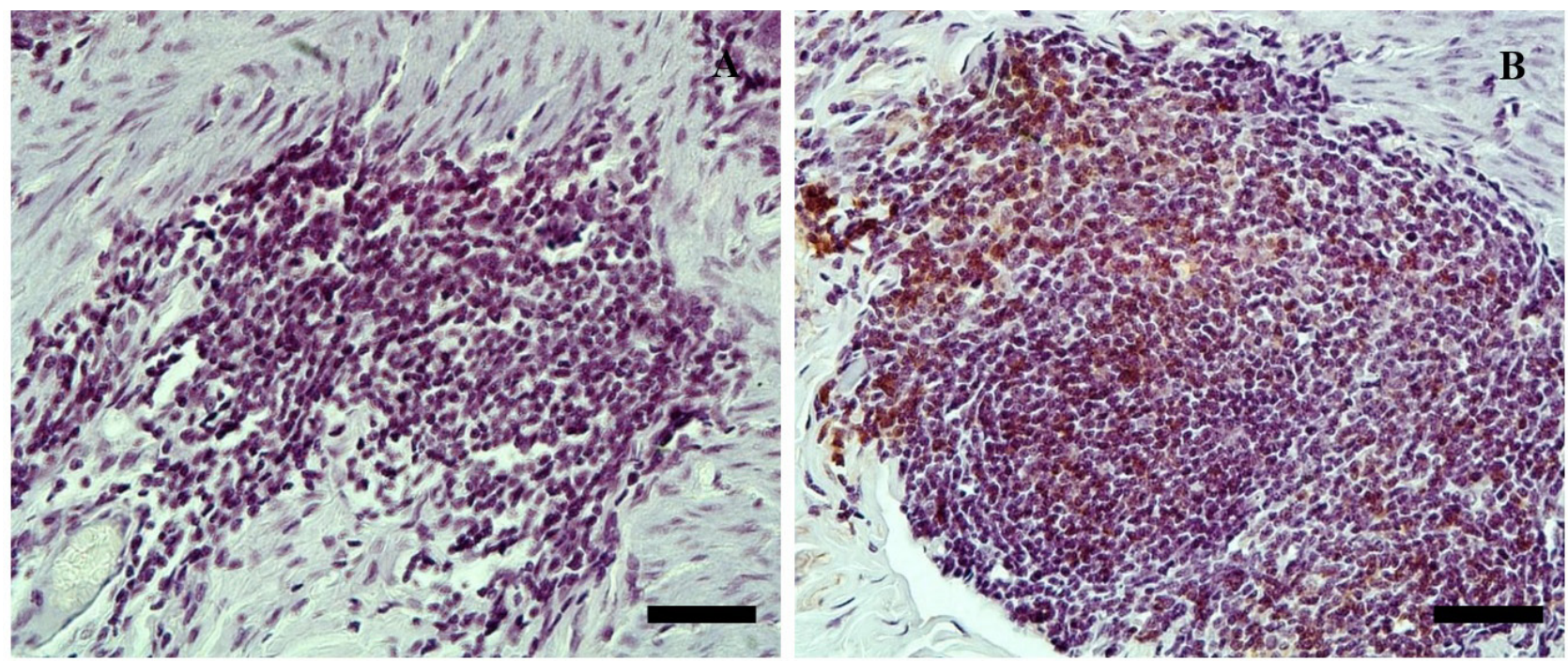

Mastiving oning

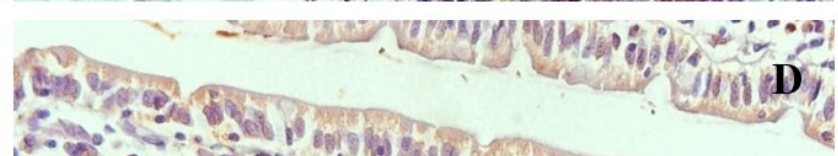

$\therefore$ a.

Q.

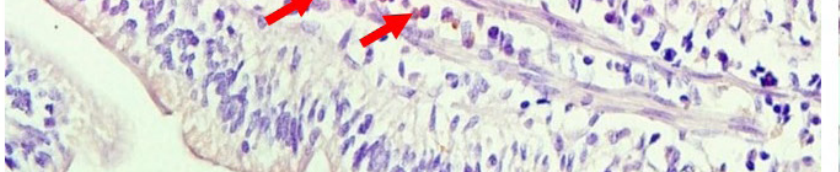
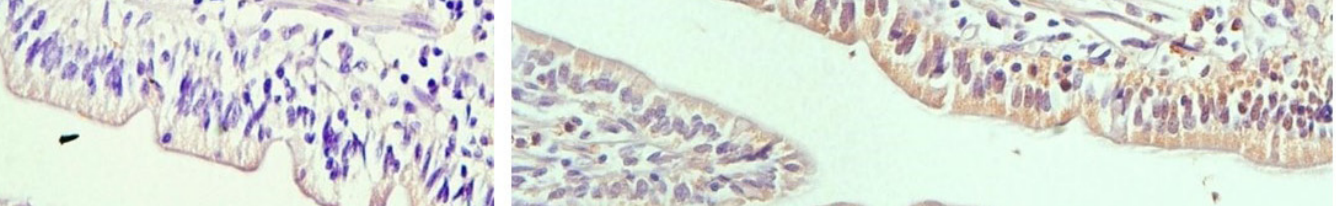

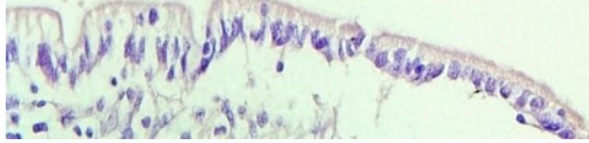
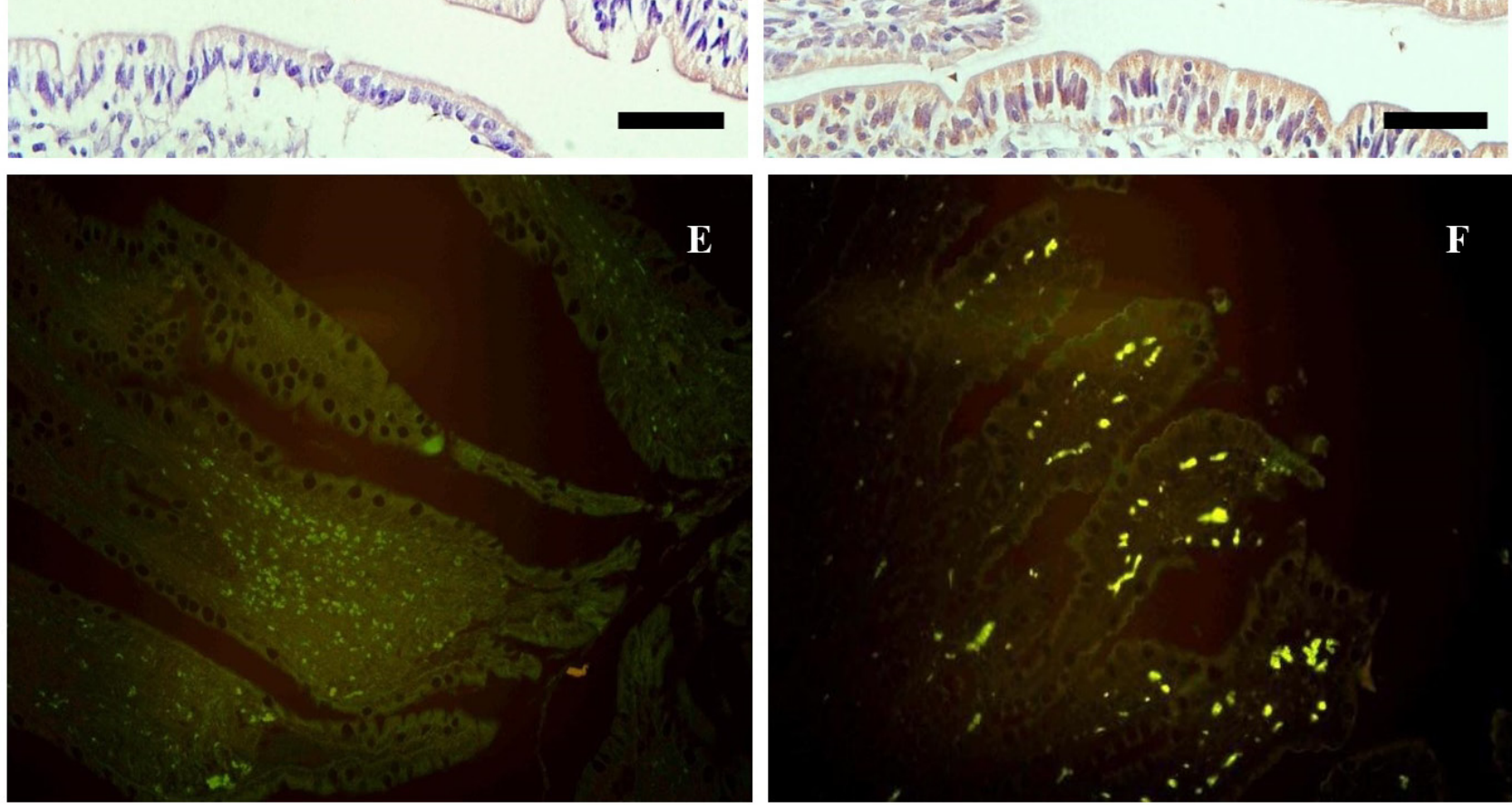

Figure 2. Histological sections of the small intestine. Figures (A, B and E) of dogs infected with Leishmania infantum intestinal amastigotes (group G1), (C, D and F) of dogs infected but without intestinal amastigotes (group G2). (A) Payer's patch in the ileum showing that there was no CD4 ${ }^{+} \mathrm{T}$ lymphocyte immunolabeling (animal 04); (B) Similar region as in A with immunostained CD8 ${ }^{+} \mathrm{T}$ lymphocytes; (C) Villus of the duodenum with immunostained $\mathrm{CD}^{+} \mathrm{T}$ lymphocytes (red arrows); (D) Similar region as in $\mathrm{C}$ with immunostained $\mathrm{CD} 8^{+} \mathrm{T}$ lymphocytes (black arrows); (E and F) villus region of jejunum and ileum, respectively, showing immunofluorescence of FoxP3 ${ }^{+} \mathrm{T}$ cells. Magnification $=40 \mathrm{x}$. Bars $=50 \mu \mathrm{m}$. Ilha Solteira, SP, Brazil, 2017. 
and colon of a dog with CVL associated with a chronic intestinal inflammatory reaction (PINTO et al., 2011, 2013; SILVA et al., 2016). Additional information about histopathological description of intestinal alterations of the dogs (G1 group) of this study can be found in Silva et al. (2016). In the present study, the increase of macrophages in intestinal tissues (small and large intestines) was observed in CVL-positive dogs (G1 and G2 groups), but hypertrophic macrophages with $L$. infantum amastigotes were seen only in G1 dogs (naturally infected dogs with intestinal amastigotes).

Table 4. Semi-quantitative analysis of $\mathrm{CD}^{+} \mathrm{T}$ lymphocytes in intestinal (duodenum, jejunum, ileum, and colon) mucosal tissues (crypt-villus unit - CVU) from dogs naturally infected with Leishmania infantum and uninfected dogs. Scores range from 1 to 4 . Ilha Solteira, SP, Brazil, 2017.

\begin{tabular}{|c|c|c|c|c|c|}
\hline \multicolumn{6}{|c|}{ Average scores for $\mathrm{CD8}^{+} \mathrm{T}$ lymphocytes by intestinal segment } \\
\hline Group & Dogs & Duodenum & Jejunum & Ileum & Colon \\
\hline G1 & $\mathrm{N}=5$ & $2.8^{\mathrm{aA}}$ & $2.2^{\mathrm{aB}}$ & $2.4^{\mathrm{aB}}$ & $3.6^{\mathrm{aA}}$ \\
\hline G2 & $\mathrm{N}=5$ & $2.6^{\mathrm{bA}}$ & $2.2^{\mathrm{aA}}$ & $2.0^{\mathrm{aA}}$ & $2.4^{\mathrm{bA}}$ \\
\hline G3 & $\mathrm{N}=3$ & $1.0^{\mathrm{cA}}$ & $1.0^{\mathrm{bA}}$ & $1.0^{\mathrm{bA}}$ & $1.0^{\mathrm{cA}}$ \\
\hline \multicolumn{6}{|c|}{ Average of the intestines } \\
\hline Group & & & & Large intestine & Intestinal tract (all) \\
\hline G1 & & & & $3.6^{\mathrm{aA}}$ & $2.75^{\mathrm{aB}}$ \\
\hline G2 & & & & $2.4^{\mathrm{bA}}$ & $2.3^{\mathrm{aA}}$ \\
\hline G3 & & & & $1.0^{\mathrm{cA}}$ & $1.0^{\mathrm{bA}}$ \\
\hline
\end{tabular}

Note: Comparison of averages by Duncan's test. Different lowercase letters ( $a, b$ and $c)$ indicate statistical significance between lines and different capital letters (A, B and C) indicate significance statistical between columns at 5\% of probability ( $\mathrm{p} \leq 0.05)$. Program R version 3.1.1 (R CORE TEAM, 2017).

Table 5. Semi-quantitative analysis of FoxP3 ${ }^{+}$Treg cells in intestinal (duodenum, jejunum, ileum, and colon) mucosal tissues (crypt-villus unit - CVU) from dogs naturally infected with Leishmania infantum and uninfected dogs. Scores range from 1 to 4. Ilha Solteira, SP, Brazil, 2017.

\begin{tabular}{|c|c|c|c|c|c|}
\hline \multicolumn{6}{|c|}{ Average scores for Treg lymphocytes $\left(\mathrm{FoxP}^{+}\right)$by intestinal segment } \\
\hline Group & Dogs & Duodenum & Jejunum & Ileum & Colon \\
\hline G1 & $\mathrm{N}=5$ & $1.4^{\mathrm{aA}}$ & $1.6^{\mathrm{aA}}$ & $1.4^{\mathrm{aA}}$ & $1.2^{\mathrm{aA}}$ \\
\hline G2 & $\mathrm{N}=5$ & $1.4^{\mathrm{aA}}$ & $1.4^{\mathrm{aA}}$ & $1.6^{\mathrm{aA}}$ & $1.6^{\mathrm{aA}}$ \\
\hline G3 & $\mathrm{N}=3$ & $1.0^{\mathrm{aA}}$ & $1.0^{\mathrm{aA}}$ & $1.0^{\mathrm{aA}}$ & $1.0^{\mathrm{aA}}$ \\
\hline \multicolumn{6}{|c|}{ Average of the intestines } \\
\hline Group & Dogs & & & Large intestine & Intestinal tract (all) \\
\hline G1 & $\mathrm{N}=5$ & & & $1.2^{\mathrm{aA}}$ & $1.4 \mathrm{a}^{\mathrm{A}}$ \\
\hline G2 & $\mathrm{N}=5$ & & & $1.6^{\mathrm{aA}}$ & $1.5^{\mathrm{aA}}$ \\
\hline G3 & $\mathrm{N}=3$ & & & $1.0^{\mathrm{aA}}$ & $1.0^{\mathrm{aA}}$ \\
\hline
\end{tabular}

Note: According to the F-test, there is no significant difference to the level of $5 \%$ probability $(\mathrm{p} \leq 0.05)$. For lowercase letters $(\mathrm{a}, \mathrm{b}$ and $\mathrm{c})$ the comparisons were made in lines and for capital letters (A, B and C) the comparisons were made in columns. $\mathrm{R}$ version 3.1.1 (R CORE TEAM, 2017).

Table 6. Correlation analysis between monocytic cells $\left(\mathrm{CD} 4^{+}\right.$and $\mathrm{CD} 8^{+} \mathrm{T}$ cells, FoxP $3^{+}$regulatory $\mathrm{T}$ cells, and macrophages) and parasite burden of Leishmania infantum amastigotes in the intestine of naturally infected dogs (G1 group). Ilha Solteira, SP, Brazil, 2017.

\begin{tabular}{|c|c|c|c|c|c|}
\hline \multicolumn{6}{|c|}{ Spearman correlation for monocytic cells semi-quantified in the intestines of dogs naturally infected with CVL } \\
\hline \multirow{2}{*}{ Group } & \multirow{2}{*}{ Variable } & \multicolumn{2}{|c|}{ Small intestine } & \multicolumn{2}{|c|}{ Large intestine } \\
\hline & & rs & P-value & rs & P-value \\
\hline \multirow{10}{*}{ G1 $(N=5)$} & SIP x SCD4+ $4^{+}$ & -0.54 & 0.343 & $-0.89^{*}$ & 0.041 \\
\hline & SIP $x$ SCD8 ${ }^{+}$ & -0.76 & 0.133 & $0.91^{*}$ & 0.03 \\
\hline & SIP x SMAC & -0.55 & 0.334 & $0.88^{*}$ & 0.046 \\
\hline & SIP $x$ SFoxP3 ${ }^{+}$ & $-0.89^{*}$ & 0.041 & 0 & 1.0 \\
\hline & $\mathrm{SCD}^{+} \times \mathrm{SCD}^{+}$ & 0.54 & 0.343 & $-0.89^{*}$ & 0.043 \\
\hline & $\mathrm{SCD}^{+}$x SMAC & -0.18 & 0.77 & $-0.92^{*}$ & 0.028 \\
\hline & $\mathrm{SCD}^{+} \times \mathrm{SFoxP}^{+}$ & 0.75 & 0.148 & -0.18 & 0.77 \\
\hline & $\mathrm{SCD}^{+} \times \mathrm{SMAC}$ & $0.89^{*}$ & 0.041 & $0.97^{*}$ & 0.006 \\
\hline & $\mathrm{SCD}^{+} \times \mathrm{SFoxP}^{+}$ & 0.71 & 0.178 & 0.41 & 0.495 \\
\hline & SMAC $x$ SFoxP $3^{+}$ & 0.46 & 0.436 & 0.4 & 0.51 \\
\hline
\end{tabular}

Note: SIP = parasitic intensity score; $\mathrm{SCD} 4^{+}=$score of $\mathrm{CD} 4^{+} \mathrm{T}$ lymphocytes; $\mathrm{SCD} 8^{+}=$score of CD $8^{+} \mathrm{T}$ lymphocytes; $\mathrm{SMAC}=$ score of macrophages; $\mathrm{SFoxP} 3=$ score of regulatory T lymphocytes (Treg); $(*)$ significant test at $5 \%$ probability $(\mathrm{p} \leq 0.05)$. Analysis carried out in accordance with linear correlation coefficient of Spearman (rs); $\mathrm{p} \leq .05$. Program R, version 3.1.1 (R CORE TEAM, 2017). 


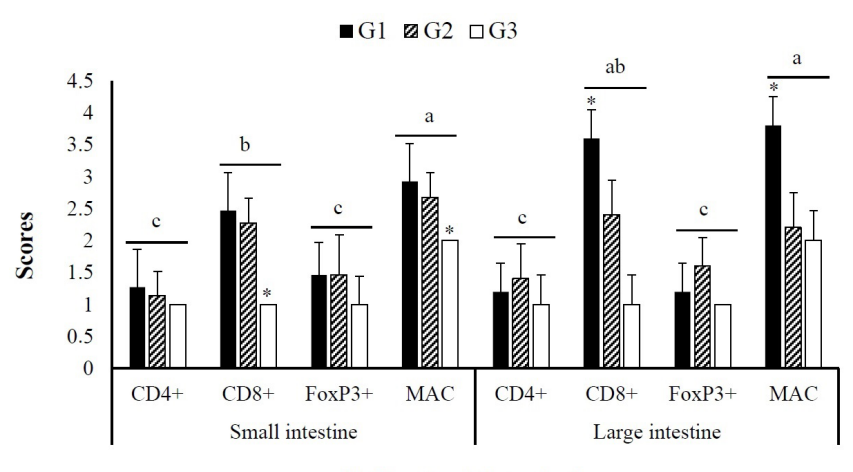

Cells - tract intestinal

Figure 3. Average scores of a semi-quantitative analysis of T lymphocytes $\left(\mathrm{CD}^{+}, \mathrm{CD}^{+}\right.$and FoxP3 $\left.{ }^{+}\right)$and macrophages (MAC) in the mucosa of the small and large intestines of dogs with canine visceral leishmaniasis (CVL). G1: Leishmania infantum-infected dogs with amastigotes in the intestine; G2: L. infantum-infected dogs without amastigotes in the intestine; and G3: uninfected (control) dogs. Average scores between cell types $\left(\mathrm{CD}^{+}, \mathrm{CD}^{+}, \mathrm{FoxP}^{+}\right.$and $\left.\mathrm{MAC}\right)$ in the small and large intestines followed by the same letter are not significantly different by the Duncan's test $(\mathrm{p} \geq 0.05)$. (*) Significant difference $(\mathrm{p} \leq 0.05)$ between groups (G1, G2 and G3). Ilha Solteira, SP, Brazil, 2017.

In this study, a semi quantitative analysis showed that G1 dogs had the highest scores for macrophages with amastigotes, particularly in the large intestines (colon) and also showed a positive correlation between the parasite burden and macrophages. These data may suggest the action of M2 macrophages in these animals. According to Moreira et al. (2016), M2 macrophages were the predominant cell type in granulomas and inflammatory infiltrates observed in the skin, lymph nodes and spleens from VL infected dogs, which coincided with the highest parasite burden found in these dogs. These evidences led the authors to conclude that the predominance of the M2 macrophages in dogs with VL favored the multiplication of $L$. infantum in organs, such as skin, lymph nodes and spleen. However, still need more studies to prove the involvement of M2 macrophages related with amastigotes of L. infantum in infected intestinal tissues as in the present work.

Macrophages with Leishmania spp. amastigotes can stimulate CD4+ $\mathrm{T}$ cells by antigen expression associated with major histocompatibility complex (MHC) class II and also CD8+ T cells via the expression of antigens associated with $\mathrm{MHC}$ class I molecules (LANG et al., 1994). As we observed in the intestinal tissues of $\mathrm{G} 1$ dogs, the increase in $\mathrm{CD}^{+} \mathrm{T}$ lymphocytes and the non-alteration of $\mathrm{CD}^{+} \mathrm{T}$ lymphocyte population suggest that the infected macrophages of these animals were expressed via MHC class I.

The high parasite burden found in the intestinal tissues of G1 dogs associated with chronic mononuclear inflammatory infiltrate represented by lymphocytes and macrophages, may also suggest that the parasite has the ability to evade the cellular immune response of the host, which may become immunocompromised over time. Previously, Passero et al. (2010) suggested that L. shawi parasites regulate different cell populations in infected BALB/c mice to preferentially express immunosuppressive activity or deactivating cytokines, thus avoiding their own destruction. It is well established that the IFN- $\gamma$ cytokine secreted by Th 1 T cells controls the growth of Leishmania spp. in macrophages (MURRAY et al., 1992) by inducing nitric oxide synthesis, which activates the microbicide functions of this cell (REINER \& LOCKSLEY, 1995). Moreover, an increase in IL-10, a cytokine secreted by $\mathrm{Th} 2 \mathrm{~T}$ cell response associated with disease progression in CVL symptomatic dogs has been observed in the absence of IFN- $\gamma$ (BOGGIATTO et al., 2010).

Cell-mediated immunity of the host plays an important role in the control of Leishmania spp. infection. In the current study, there was no significant difference in $\mathrm{CD}^{+} \mathrm{T}$ cell scores among the animals from $\mathrm{G} 1, \mathrm{G} 2$ or G3 groups ( $\mathrm{p} \geq 0.05)$. In addition, $\mathrm{CD} 4^{+}$ $T$ cell population had no increase in intestinal tissues even in G1 dogs with high parasite burden in the mucosa (villi and crypts) and submucosa, which cellular scores were inversely correlated with parasite burden. In dogs infected with L. infantum, Bourdoiseau et al. (1997) showed a reduction of $\mathrm{CD}^{+} \mathrm{T}$ lymphocytes numbers in the peripheral blood concomitant with the proliferation of the parasite in tissue macrophages, suggesting the absence of an effective immune response to eliminate the parasite. According to Alvar et al. (2004), the reduction of $\mathrm{CD}^{+}{ }^{+} \mathrm{T}$ cell levels during the progression of disease in dogs was indicative of the failure of the host to control the parasite, allowing it to migrate to other tissues, increasing the parasite load and the infectivity of the host.

According to Pinelli et al. (1994); Brachelente et al. (2005); Barbiéri (2006) and Cruz-Chan et al. (2014) severe and progressive CVL in infected dogs was associated with a predominantly Th2 humoral immune response that was not able to control the infection. Similarly, Stäger and Rafati (2012) showed in rats experimentally infected with $L$. major in subcutaneous tissue that IFN- $\gamma$ production by Th 1 cells was essential to control the infection, but in contrast, Th2 response resulted in susceptibility to the disease. Similarly, Carvalho et al. (2012) also reported that BALB/c mice experimentally infected with L. (Leishmania) amazonensis presented a Th2 response that was related to susceptibility to the parasite. Moreover, BALB/c strain mice experimentally infected with L. (Vianna) brasiliensis triggered a Th1 cellular immune response in the skin associated with resistance to the parasite. The considerable number of infected macrophages in intestinal tissues of G1 group dogs suggests the intestinal susceptibility of these animals to $L$. infantum. However, studies that relate resistance or susceptibility of dogs to intestinal CVL are still lacking.

Pinelli et al. (1995) demonstrated the involvement of CD8 ${ }^{+}$ lymphocytes in resistance to canine VL. These lymphocytes were detected in asymptomatic dogs experimentally infected with $L$. (L.) infantum and subsequent lysis of Leishmania-infected macrophages. In contrast, symptomatic dogs showed a reduced lymphoproliferative response to specific antigenic stimulation, resulting in a lower ability of CD8+ T lymphocytes to lyse infected macrophages. In our study, G1 dogs showed high levels of $\mathrm{CD}^{+} \mathrm{T}$ lymphocytes and low levels of $\mathrm{CD}^{+}{ }^{+}$in intestinal tissues. In addition, $\mathrm{CD} 8+\mathrm{T}$ lymphocyte scores correlated positively with parasite burden in intestinal tissues from dogs of G1 group; significantly higher in the duodenum and colon, where parasite burdens were more intense. Thus, it is likely that $\mathrm{CD}^{+}$mediated cellular immune response was not able to control the intestinal infection, possibly due to the 
inability of these cells to exert their cytotoxic activity in infected macrophages as suggested by Pinelli et al. (1995). In a study of $\mathrm{CD}^{+} \mathrm{T}$ cells role in Leishmania donovani infection, Joshi et al. (2009) reported that $\mathrm{CD}^{+} \mathrm{T}$ cell responses against the parasite were defective in their cytotoxic activity toward infected cells.

We also detected the presence of parasites in Peyer's patches and $\mathrm{CD}^{+} \mathrm{T}$ lymphocytes in higher scores than $\mathrm{CD}^{+} \mathrm{T}$ cells indicating that the parasites were invading the lymphoid protective tissue in the intestinal mucosa and that the immune system was not able to control the expansion of the parasite in these organs. For Stäger $\&$ Rafati (2012) the protective role of CD8 + T cells during infection by Leishmania spp. is controversial, particularly because of the diversity of different Leishmania species with different tropisms that is reflected in the various clinical manifestations of the disease.

According to Yurdakul (2005), the inability of T cells to activate macrophages to destroy Leishmania spp. amastigotes appears to be the primary defect in this disease, which is associated with parasite multiplication and migration, affecting multiple organs of the host. Our results showed that $\mathrm{CD} 8^{+} \mathrm{T}$ lymphocytes were unable to destroy parasitized macrophages, suggesting that other anti-inflammatory components such as regulatory $\mathrm{T}$ cells could mediate immune response, which may explain the lack of resolution and the maintenance and progression of the disease. The high parasite burden in the colon mucosa with only mild pathological alterations led Pinto et al. (2011) and Pinto et al. (2013) to suggest that L. infantum may benefit of the intestinal immune regulatory response (immunological tolerance). In fact, this type of immunoregulatory response could be mediated by Treg cells. More recently, Figueiredo et al. (2014) suggested that Treg cells could mediate both intestinal leishmaniasis and the homeostasis of the colon under normal physiological conditions. In that study, cellular expression of toll-like receptor 2 (TLR2) and IL-4 was more evident in the colon, whereas TLR9-expressing cells, IL-10, and TNF- $\alpha$ were more frequent in the jejunum, which had fewer parasites than the colon. These conflicting findings indicate that further studies are needed to elucidate important immune mechanisms related to parasitic infection in the intestinal wall.

In our study, Treg cell scores in intestinal tissues of dogs in the G1 group (infected dogs with amastigotes in the intestine) were low and not significantly different from those in the G2 and G3 groups. Similarly, Rodrigues et al. (2009) observed a reduction in the presence of FoxP $3^{+} \mathrm{T}$ cells in the spleen of Balb/c mice infected with $L$. infantum with a simultaneous increase in parasite burden. The decrease of FoxP3 ${ }^{+}$regulatory $\mathrm{T}$ cells observed in dogs with CVL can be due to persistent immune activation that triggers the infection process (SILVA et al., 2014). The results of that study suggested that different immunosuppressive factors other than those mediated by FoxP3 ${ }^{+} \mathrm{T}$ cells were involved in the immune response to CVL, but further studies should be conducted to elucidate this question.

\section{Conclusions}

We showed here that the intestinal tissues of dogs naturally infected with L. infantum (G1 group) were susceptible to high parasite burden and that parasite burden correlated positively with chronic inflammatory mononuclear infiltrates represented by $\mathrm{CD}^{+} \mathrm{T}$ lymphocytes and macrophages. In addition, the increase of $\mathrm{CD}^{+} \mathrm{T}$ cells and macrophages population associated with high parasite loads, but no changes of $\mathrm{CD}^{+} \mathrm{T}$ cells and FoxP3 ${ }^{+}$Treg cells suggest a possible immunoregulation by the parasite not dependent on Treg cells.

\section{Acknowledgements}

The authors thank São Paulo Research Foundation (FAPESP) for financial support (no 2013/13875-5) and the Zoonotic Disease Control Center (ZCC) of Ilha Solteira, SP for donating the biological material from the dogs.

\section{References}

Adamama-Moraitou KK, Rallis TS, Koytinas AF, Tontis D, Plevraki K, Kritsepi M. Asymptomatic colitis in naturally infected dogs with Leishmania infantum: a prospective study. Am J Trop Med Hyg 2007; 76(1): 53-57. PMid:17255229.

Alvar J, Cañavate C, Molina R, Moreno J, Nieto J. Canine leishmaniasis. Adv Parasitol 2004; 57(4): 1-88. PMid:15504537.

Anderson DC, Buckner RG, Glenn BL, MacVean DW. Endemic canine leishmaniasis. Vet Pathol 1980; 17(1): 94-96. PMid:7352367.

Barbiéri CL. Immunology of canine leishmaniasis. Parasite Immunol 2006; 28(7): 329-337. PMid:16842269.

Blavier A, Keroack S, Denerolle P, Goy-Thollot I, Chabanne L, Cadoré JL, et al. Atypical Forms of Canine Leishmaniosis. Vet J 2001; 162(2): 108-120. PMid:11531395.

Boer OJ, Van der Loos CM, Teeling P, Van der Wal AC, Teunissen MBM. Immunohistochemical analysis of regulatory $\mathrm{T}$ cell markers FOXP3 and GITR on CD4+CD25+ T cells in normal skin and inflammatory dermatoses. J Histochem Cytochem 2007; 55(9): 891-898. PMid:17478450.

Boggiatto PM, Ramer-Tait AE, Metz K, Kramer EE, Gibson-Corley K, Mullin K, et al. Immunologic indicators of clinical progression during canine Leishmania infantum infection. Clin Vaccine Immunol 2010; 17(2): 267-273. PMid:20032217.

Bourdoiseau G, Bonnefont C, Hoareau E, Boehringer C, Stolle T, Chabanne L. Specific IgG1 and IgG2 antibody and lymphocyte subset levels in naturally Leishmania infantum-infected treated and untreated dogs. Vet Immunol Immunopathol 1997; 59(1-2): 21-30. PMid:9437823.

Brachelente C, Müller N, Doherr MG, Sattler U, Welle M. Cutaneous leishmaniasis in naturally infected dogs is associated with a T Helper-2biased immune response. Vet Pathol 2005; 42(2): 166-175. PMid:15753470.

Carvalho AK, Silveira FT, Passero LFD, Gomes CMC, Corbett CEP, Laurenti MD. Leishmania (V.) braziliensis and $L$. (L.) amazonensis promote differential expression of dendritic cells and cellular immune response in murine model. Parasite Immunol 2012; 34(8-9): 395-403. PMid:22587683.

Cortes S, Roláo N, Ramada J, Campino L. PCR as a rapid and sensitive tool in the diagnosis of human and canine leishmaniasis using Leishmania donovani s.l. - Specific kinetoplastid primers. Trans $R$ Soc Trop Med Hyg 2004; 98(1): 12-17. PMid:14702834. 
Cruz-Chan JV, Aguilar-Cetina AC, Villanueva-Lizama LE, MartínezVega PP, Ramírez-Sierra MJ, Rosado-Vallado ME, et al. A canine model of experimental infection with Leishmania (L.) mexicana. Parasit Vectors 2014; 7: 361. PMid:25108307.

Delfs MW, Furukawa Y, Mitchell RN, Lichtman AH. CD8+ T cell subsets TC1 and TC2 cause different histopathologic forms of murine cardiac allograft rejection. Transplantation 2001; 71(5): 606-610. PMid:11292288.

Feitosa MM, Ikeda FA, Luvizotto MCR, Perri SHV. Aspectos clínicos de cães com leishmaniose visceral no município de Araçatuba, São Paulo, Brasil. Clin Vet 2000; 5(28): 36-44.

Ferrer L, Juanola B, Ramos JA, Ramis A. Chronic colitis due to Leishmania infection in two dogs. Vet Pathol 1991; 28(4):342-343. PMid:1949514.

Figueiredo MM, Deoti B, Amorim IF, Pinto AJW, Moraes A, Carvalho CS, et al. Expression of regulatory T-cells in jejunum, colon, and cervical and mesenteric lymph node of dogs naturally infected with Leishmania infantum. Infect Immun 2014; 82(9): 3704-3712. PMid:24935975.

Fontenot JD, Gavin MA, Rudensky AY. Foxp3 programs the development and function of $\mathrm{CD}^{+} \mathrm{CD} 25^{+}$regulatory T cells. Nat Immunol 2003; 4(4): 330-336. PMid:12612578.

Galati EAB, Nunes VLB, Rego FA Jr, Oshiro ET, Chang MR. Estudo de flebotomíneos (Diptera: Psychodidae) em foco de leishmaniose visceral no Estado de Mato Grosso do Sul, Brasil. Rev Saude Publica 1997; 31(4): 378-390. PMid:9595767.

González JL, Fermin ML, Garcia P, Rollan E, Castańo M. Erosive colitis in experimental canine Leishmaniasis. Zentralbl Veterinarmed B 1990; 37(5): 377-382. PMid:2396485.

Herath S, Kropf P, Müller I. Cross-talk between CD8(+) and CD4(+) T cells in experimental cutaneous leishmaniasis: CD8(+) T cells are required for optimal IFN-gamma production by CD4(+) T cells. Parasite Immunol 2003; 25(11-12): 559-567. PMid:15053777.

Joshi T, Rodriguez S, Perovic V, Cockburn IA, Stäger S. B7-H1 blockade increases survival of dysfunctional $\mathrm{CD}^{+} \mathrm{T}$ cells and confers protection against Leishmania donovani infections. PLoS Pathog 2009; 5(5): e1000431. PMid:19436710.

Keenan CM, Hendricks LD, Lightner L, Webster HK, Johnson AJ. Visceral leishmaniasis in the German Shepherd dog. I. Infection, clinical disease, and clinical pathology. Vet Pathol 1984; 21(1): 74-79. PMid:6710816.

Lang T, Chastellier C, Frehel C, Hellio R, Metezeau P, Leao SS, et al. Distribution of MHC class I and of MHC class II molecules in macrophages infected with Leishmania amazonensis. J Cell Sci 1994; 107(Pt 1): 69-82. PMid:8175924.

Luca PM, Mayrink W, Alves CR, Coutinho SG, Oliveira MP, Bertho $\mathrm{AL}$, et al. Evaluation of the stability and immunogenicity of autoclaved and nonautoclaved preparations of a vaccine against American tegumentary leishmaniasis. Vaccine 1999; 17(9-10): 1179-1185. PMid:10195630.

Mendez S, Reckling SK, Piccirillo CA, Sacks D, Belkaid Y. Role for CD $4^{+}$ $\mathrm{CD} 25^{+}$regulatory $\mathrm{T}$ cells in reactivation of persistent leishmaniasis and control of concomitant immunity. J Exp Med 2004; 200(2): 201-210. PMid:15263027.

Mills CD, Kincaid K, Alt JM, Heilman MJ, Hill AM. M-1/M-2 macrophages and the Th1/Th2 paradigm. J Immunol 2000; 164(12): 6166-6173. PMid:10843666.

Moreira PR, Fernando FS, Montassier HJ, André MR, Oliveira-Vasconcelos R. Polarized M2 macrophages in dogs with visceral leishmaniasis. Vet Parasitol 2016; 226: 69-73. PMid:27514887.
Müller I, Pedrazzini T, Kropf P, Louis J, Milon G. Establishment of resisteance to Leishmania major infection in susceptible BALB/c mice requires parasite-especific CD8 ${ }^{+} \mathrm{T}$ cells. Int Immunol 1991; 3(6): $587-$ 597. PMid:1909563.

Murray HW, Squires KE, Miralles CD, Stoeckle MY, Granger AM, Granelli-Piperno A, et al. Acquired resistance and granuloma formation in experimental visceral leishmaniasis. Differential T cell and lymphokine roles in initial versus established immunity. J Immunol 1992; 148(6): 1858-1863. PMid:1541824.

Naderer T, McConville MJ. The Leishmania-macrophage interaction: A metabolic perspective. Cell Microbiol 2008; 10(2):301-308. PMid:18070117.

Nieto CG, García-Alonso M, Requena JM, Mirón C, Soto M, Alonso $\mathrm{C}$, et al. Analysis of the humoral immune response against total and recombinant antigens of Leishmania infantum: Correlation with disease progression in canine experimental leishmaniasis. Vet Immunol Immunopathol 1999; 67(2): 117-130. PMid:10077418.

Ohta N, Fukase S, Fuse T, Aoyagi M. Th1, Th2, Tc1 and Tc2 cells of patients with otolaryngological diseases. Allergol Int 2004; 53(3): 199-203.

Oliveira TMFS, Furuta PI, Carvalho D, Machado RZ. A study of crossreactivity in serum samples from dogs positive for Leishmania sp., Babesia canis and Ehrlichia canis in enzyme-linked immunosorbent assay and indirect fluorescent antibody test. Rev Bras Parasitol Vet 2008; 17(1): 7-11. PMid:18554433.

Passero LFD, Marques C, Vale-Gato I, Corbett CEP, Laurenti MD, Santos-Gomes G. Histopathology, humoral and cellular immune response in the murine model of Leishmania (Viannia) shawi. Parasitol Int 2010; 59(2): 159-165. PMid:20060062.

Pinelli E, Gonzalo RM, Boog CJP, Rutten VP, Gebhard D, del Real G, et al. Leishmania infantum-specific $\mathrm{T}$ cell lines derived from asymptomatic dogs that lyse infected macrophages in a major histocompatibility complexrestricted manner. Eur J Immunol 1995; 25(6): 1594-1600. PMid:7614987.

Pinelli E, Killick-Kendrick R, Wagenaar J, Bernadina W, del Real G, Ruitenberg J. Cellular and humoral immune responses in dogs experimentally and naturally infected with Leishmania infantum. Infect Immun 1994; 62(1): 229-235. PMid:8262632.

Pinto AJW, Figueiredo MM, Ferreira RA, Caliari MV, Tafuri WL. Unusual small intestine inflammatory lesions in a dog with visceral leishmaniasis. Braz J Vet Pathol 2013; 6(1): 19-25.

Pinto AJ, Figueiredo MM, Silva FL, Martins T, Michalick MS, Tafuri WL, et al. Histopathological and parasitological study of the gastrointestinal tract of dogs naturally infected with Leishmania infantum. Acta Vet Scand 2011; 53(1): 67. http://dx.doi.org/10.1186/1751-0147- 53-67. PMid:22166041.

$\mathrm{R}$ Core Team. $R$ : a language and enviroment for statistical computing [online]. Vienna: R Foundation for Statistical Computing; 2017 [cited 2017 June 2]. Available from: http://www.R-project.org/

Reiner S, Locksley R. The Regulation of Immunity to Leshmania major. Annu Rev Immunol 1995; 13: 151-177. PMid:7612219.

Rodrigues CAT, Batista LFS, Teixeira MCA, Pereira AM, Santos POM, de Sá Oliveira GG, et al. Peripheral blood mononuclear cell supernatants from asymptomatic dogs immunized and experimentally challenged with Leishmania chagasi can stimulate canine macrophages to reduce infection in vitro. Vet Parasitol 2007; 143(3-4): 197-205. PMid:17045743.

Rodrigues OR, Marques C, Soares-Clemente M, Ferronha MH, SantosGomes GM. Identification of regulatory $\mathrm{T}$ cells during experimental Leishmania infantum infection. Immunobiology 2009; 214(2): 101-111. PMid:19167988. 
Silva DT, Neves MF, Queiroz NMGP, Spada JCP, Alves ML, Flóro e Silva $\mathrm{M}$, et al. Correlation study and histopathological description of intestinal alterations in dogs infected with Leishmania infantum. Rev Bras Parasitol Vet 2016; 25(1): 24-36. PMid:26982556.

Silva KLO, Andrade MMC, Melo LM, Perosso J, Vasconcelos RO, Munari DP, et al. CD4+FOXP3+ cells produce IL-10 in the spleens of dogs with visceral leishmaniasis. Vet Parasitol 2014; 202(3-4): 313-318. PMid:24703254.

Stäger S, Rafati S. CD8+ T cells in Leishmania infections: friends or foes? Front Immunol 2012; 3: 5. PMid:22566891.

Tafuri WL, Santos RL, Arantes RME, Gonçalves R, Melo MN, Michalick MSM, et al. An alternative immunohistochemical method for detecting Leishmania amastigotes in paraffin-embedded canine tissues. J Immunol Methods 2004; 292(1-2): 17-23. PMid:15350508.
Toplu N, Aydogan A. An immunohistochemical study in cases with usual and unusual clinicopathological findings of canine visceral leishmaniosis. Parasitol Res 2011; 109(4): 1051-1057. PMid:21479577.

Tsagozis P, Karagouni E, Dotsika E. CD8 ${ }^{+}$T cells with parasite-specific cytotoxic activity and a $\mathrm{Tc} 1$ profile of cytokine and chemokine secretion develop in experimental visceral leishmaniasis. Parasite Immunol 2003; 25(11-12): 569-579. PMid:15053778.

Wheeler RJ, Gluenz E, Gull K. The cell cycle of Leishmania: Morphogenetic events and their implications for parasite biology. Mol Microbiol 2011; 79(3): 647-662. PMid:21255109.

World Health Organization - WHO. Control of the leishmaniases. World Health Organ Tech Rep Ser 2010; 949: 22-26.

Yurdakul P. Immunopathogenesis of Leishmania Infections. Mikrobiyol Bul 2005; 39(3): 363-381. PMid:16358498. 